\title{
MENINGKATKAN KEMAMPUAN MENULIS KARANGAN SISWA KELAS V SD NEGERI 87 KENDARI MELALUI MODEL PEMBELAJARAN KONTEKSTUAL
}

\author{
Oleh: \\ WAMPIKA
}

Email: wampika@gmail.com

\begin{abstract}
Abstrak: Tujuan penelitian adalah untuk meningkatkan kemampuan menulis karangan siswa kelas VI SD Negeri 87 Kendari melalui model pembelajaran kontekstual. Manfaat penelitian ini adalah: 1) bagi siswa, meningkatkan kemampuan menulis karangan berdasarkan pengalaman dengan memperhatikan pilihan kata dan penggunaan ejaan, 2) bagi guru, meningkatkan kemampuan menerapkan model-model pembelajaran yang inovatif sesuai dengan keterampilan menulis, 3) bagi sekolah, dapat dijadikan sebagai bahan masukan bagi peningkatan kualitas pendidikan yang mengarah pada peningkatan kompetensi lulusan dan prestasi siswa pada mata pelajaran bahasa Indonesia di SD Negeri 87 Kendari Hasil penelitian menunjukkan bahwa ketuntasan hasil belajar siswa pada siklus I yaitu $72,72 \%$ dengan rata-rata sebesar 74,2 dan pada siklus II ketuntasan hasil belajar siswa meningkat menjadi $90,90 \%$ dengan rata-rata sebesar 79,5.Aktivitas belajar siswa siklus I mencapai persentase sebesar $70 \%$ dan pada siklus II sebesar 90\%. Aktivitas mengajar guru siklus I mencapai persentase sebesar $70 \%$ dan pada siklus II mencapai 90\%. Kesimpulan penelitian adalah: 1) penerapan pendekatan kontekstual dalam mengajarkan bahasa Indonesia pada materi menulis karangan dapat meningkatkan hasil belajar siswa yakni rata-rata hasil belajar siswa pada siklus I sebesar 74,2 dengan persentase ketuntasan 72,72\% meningkat pada siklus II yakni rata-rata hasil belajar siswa mencapai 79,5 dengan persentase ketuntasan $90,90 \%$; 2) persentase kegiatan siswa dalam mengikuti pembelajaran meningkat dari siklus I sebesar 70\% menjadi $90 \%$ pada siklus II; 3) Persentase kegiatan guru dalam melaksanakan pembelajaran pada siklus I sebesar $70 \%$ meningkat menjadi $90 \%$ pada siklus II.
\end{abstract}

\section{Kata Kunci: Pembelajaran Kontekstual, Kemampuan Menulis Karangan}

\section{PENDAHULUAN}

Menulis adalah melahirkan pikiran atau gagasan (seperti mengarang, membuat surat dengan tulisan (Tim Penyusun Kamus, 1998:968). Menulis adalah menemukan atau melukiskan lambang-lambang grafik yang menggambarkan suatu bahasa yang dipahami oleh seseorang. Menulis dapat diartikan sebagai aktivitas pengekspresian ide, gagasan, pikiran atau perasaan ke dalam lambang-lambang kebahasaan (bahasa tulis) (Rofiudin 1997:263). Jadi pengertian menulis adalah melukiskan lambang lambang yang menggambarkan suatu bahasa dari suatu pengekspresian ide, gagasan, perasaan, dan pikiran yang dapat dibaca dan dipahami oleh orang lain.

Menurut Hernowo (2004), keterampilan menulis diarahkan agar siswa mampu menuangkan segala pikiran, pengalaman, pesan perasaan, gagasan, pendapat imajinasi dalam bentuk bahasa tulisan secara benar. Kebenarannya dapat dilihat dari segi kebahasaan, isi, dan makna. Tujuan ini identik dengan tujuan 
belajar berbicara. Namun demikian, menuangkan segala pesan, gagasan, pendapat dan lain-lain dalam bentuk tulisan jauh lebih sulit dibandingkan dengan bahasa lisan. Padahal, tulisan akan lebih barmakna dikala orang bermaksud mengingat kembali. Tulisan dapat terdokumentasikan lebih baik dan dapat dilihat ulang. Karena itu pembelajaran menulis bagi siswa harus dianggap penting. Hasil analisis ulangan harian siswa kelas VI SD Negeri 87 Kendari menunjukkan bahwa nilai keterampilan menulis termasuk nilai yang paling rendah dari empat keterampilan berbahasa. Nilai rata-rata yang dicapai siswa hanya mencapai 65 , dengan persentase ketuntasan sebesar 38,9 \% sementara standar ketuntasan minimal ditetapkan sebesar 70. Hal ini menunjukkan bahwa dalam melaksanakan pembelajaran menulis, guru perlu melakukan proses kreatif untuk meningkatkan hasil belajar siswa.

Kegiatan pembelajaran selalu ditandai adanya interaksi antara guru dengan siswa, siswa dengan siswa, dan siswa dengan sumber belajar. Interaksi tersebut dapat terjadi secara searah maupun terjadi secara timbal balik dari guru kepada siswa atau sebaliknya.Guru memiliki peran yang besar dalam rangka menentukan model interaksi atau kegiatan yang akan dipilih. Peran guru dalam melakukan kegiatan untuk memilih dan menentukan model interaksi yang terjadi antara guru dengan siswa disebut mengajar. Sedangkan kegiatan siswa dalam melakukan kegiatan interaksi disebut belajar.

Menurut Slameto (1991: 84), mengemukakan bahwa mengajar adalah kegiatan mengorganisasi sumber belajar yang bertujuan untuk membantu dan menggairahkan siswa belajar. Pada saat terjadi interaksi dengan siswa, maka guru memilih dan melakukan dengan cara-cara tertentu agar kegiatan interaksi dengan siswa dapat berjalan dengan kondusif, sehingga tujuan yang diharapkan dapat tercapai. Metode mengajar memiliki peranan yang sangat penting dalam proses belajar mengajar.Soetomo (1993: 144), menyebutkan "metode mengajar sebagai suatu alat untuk mencapai tujuan pengajaran yang ingin dicapai, sehingga semakin baik penggunaan metode mengajar semakin berhasillah pencapaian tujuan".

Penggunaan metode mengajar secara tepat dapat menumbuhkan minat siswa untuk dapat mengikuti kegiatan belajar mengajar dengan baik, sehingga kreatifitas anak akan muncul dan berkembang dengan baik pula. Namun sebaliknya, jika penggunaan metode mengajar ini kurang tepat, maka akan menjadi tidak bermakna bahkan dapat mematikan kreativitas siswa. Pemilihan metode mengajar sangat tergantung pada situasi dan kondisi pada saat guru mengajar. Tidak semua metode mengajar selalu tepat digunakan untuk menyampaikan materi pelajaran. Slameto (1991: 90), menjelaskan bahwa strategi adalah suatu rencana tentang cara-cara pendayagunaan potensi dan sarana yang ada untuk meningkatkan efektivitas dan efisiensi (pengajaran)". Dengan demikian di dalam strategi sudah terkandung unsur metode belajar mengajar, teknik mengajar, serta penggunaan alat-alat bantu mengajar dan media pembelajaran.

Berdasarkan uraian tersebut dapat dirumuskan bahwa strategi belajar mengajar merupakan suatu keseluruhan perencanaan tentang kegiatan belajar mengajar yang mencakup pemanfaatan sumber-sumber pembelajaran secara maksimal guna mencapai tujuan pembelajaran secara efektif dan efisien. Sumbersumber belajar yang dimaksud dapat berupa serangkaian metode yang digunakan, teknik-teknik penggunaan sarana dan prasarana yang ada, pengelolaan situasi dan 
kondisi yang kondusif, bahkan juga merumuskan tingkat keberhasilan yang dicapai dengan jalan mengelola sistem penilaian yang digunakan.

Dalam proses kegiatan belajar mengajar, strategi belajar mengajar juga mengkaji tentang alternatif-alternatif kegiatan belajar mengajar yang akan dilaksanakan, untuk selanjutnya diseleksi mana yang paling tepat digunakan untuk mencapai tujuan yang diharapkan. Pemilihan terhadap alternatif-alternatif yang ada haruslah didasarkan pada suatu kondisi siswa, baik secara individu maupun secara kelompok, sehingga akan memberikan jaminan bahwa alternatif tersebut dapat membantu siswa untuk menguasai tugas-tugas belajar yang telah diidentifikasikan berdasarkan permasalahan yang terjadi. Apabila seseorang menggunakan buah pikiran, gagasan, perasaan, pengalaman atau lainya ke dalam bahasa tulis, kegiatan tersebut adalah kegiatan mengarang. Untuk dapat menyampaikan suatu pikiran, gagasan, perasaan, pengalaman atau lainya, seseorang perlu memiliki pembendaharaan kata yang memadai, terampil menyusun kata-kata menjadi kalimat yang jelas, dan mahir memakai bahasa secara efektif.

\section{Pembelajaran Kontekstual}

Pembelajaran kontekstual adalah konsep yang membantu guru mengaitkan antaramateri yang diajarkan dengan situasi dunia nyata dan mendorong siswamembuat hubungan antara pengetahuan yang dimilikinya denganpenerapannya dalam kehidupan sehari-hari. Ada tujuh komponenutama pembelajaran kontekstual yang efektif, yaitu konstruktivisme(constructivism), bertanya (question), menemukan (inquiry),masyarakat belajar (learning community), pemodelan (modelling), danpenilaian sebenarnya (authentic assesment) (Depdiknas, 2002:32).

Langkah-langkah pembelajaran kontekstual menurut Paul Suparno (1997: 67) sebagai berikut: (1) mengarahkan siswa agar menerapkan strategi mereka sendiri dalam merumuskan masalah, (2) melakukan observasi terlebih dahulu, (3) mengkonfirmasikan kepada siswa tentang apa yang sudah diketahui, dan mengarahkan perhatian pada aspek yang belum diketahuinya, (4) mengarahkan siswa pada kelompok-kelompok belajar yang heterogen, (5) mengarahkan $\mathrm{s}^{\mathrm{i} \cdots \cdots}$ ? pada proses pembelajaran yang berpusat pada siswa, (6) memberikan contoh dalam bentuk konkret bukan khayalan yang membuat siswa bertanya, dan (7) memberikan respon kepada setiap pertanyaan siswa.

\section{METODE PENELITIAN \\ Jenis Penelitian}

Penelitian ini termasuk jenis penelitian tindakan kelas (classroomaction research), karena penelitian dilakukan untuk memecahkan masalah pembelajaran di kelas. Penelitian tindakan kelas adalah suatu bentuk kajian yang bersifat reflektif.

\section{Setting Penelitian}

Penelitian ini akan dilaksanakan pada semester genap tahun pelajaran 2019/2020 di kelas VI SD Negeri 87 Kendari

\section{Subjek Penelitian}

Subjek dalam penelitian ini adalah guru dan siswa kelas VI SD Negeri 87 Kendari yang berjumlah 22 orang yang terdiri atas 15 laki-laki dan 7 perempuan.

\section{Faktor yang Diteliti}

Faktor yang diteliti dalam penelitian ini adalah: 
1. Guru, yaitu kemampuan guru mempersiapkan materi pelajaran dan melaksanakan pembelajaran dengan menerapkan pendekatan kontekstual; dan

2. Siswa, yaitu kemampuan menuliskarangan, dan aktivitas siswa dalam proses pembelajaran.

\section{Rencana Tindakan}

Penelitian ini dilaksanakan dalam dua siklus. Setiap siklus dikenai perlakuan yang sama (alur kegiatan yang sama) dan membahas kegiatan pembelajaran sesuai Rencana Pelaksanaan Pembelajaran (RPP) yang telah dibuat, selanjutnya dilakukan pengamatan dan diakhiri dengan tes formatif di akhir masing-masing putaran (evaluasi siklus).

Pelaksanaan tindakan pada setiap siklus terdiri atas empat tahap, yaitu: perencanaan (planning), tindakan (action), observasi dan evaluasi (observation and evaluation), refleksi (reflection).Adapun alur penelitian tindakan kelas sebagaimana gambar 3.1 berikut:

Gambar 3.1 Spiral Tindakan Kelas

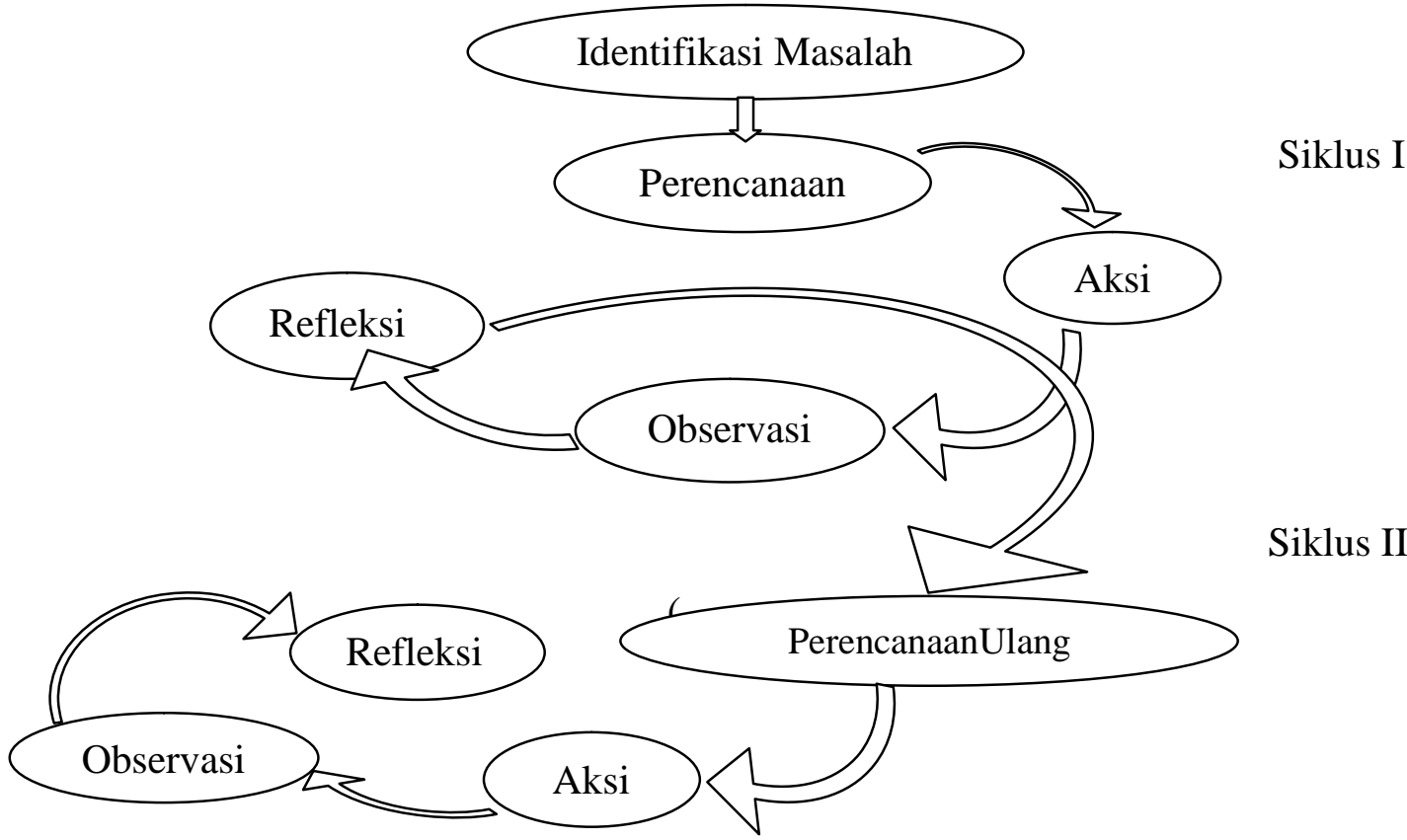

Adaptasi dari Hapkins dalam Mukhlis, 2000). Setiap siklus penelitian tindakan kelas, terdiri atas empat tahapan yang terdiri dari: 1) Perencanaan tindakan(planning); 2) Pelaksanaan tindakan(action); 3) Observasi dan evalusi (observation and evaluation); dan 4) Refleksi(reflection).

\section{Pelaksanaan Siklus I}

Secara rinci setiap tahapan kegiatan dijelaskan sebagai berikut.

a. Perencanaan

Kegiatan yang dilakukan pada tahap ini adalah:

1. Membuat skenario pembelajaran dengan menerapkan pendekatan kontekstual;

2. Membuat/menyiapkan:
a. alat bantu/alat peraga
b. lembar kegiatan siswa (LKS)
c. lembar observasi guru 
d. jurnal refleksi diri

e. mendesain/menbuat alat evaluasi berupa soal

b. Pelaksanaan Tindakan

Kegiatan yang dilakukan pada tahap ini adalah melaksanakan skenario pembelajaran.

c. Observasidan Evaluasi

Pada tahap pengamatan ini dijalankan bersamaan dengan kegiatan pembelajaran yang dilakukan dengan teman sejawat (kolaborator)dengan menggunakan lembar observasi.Aspek yang dinilai dalam kemampuan menulis karangan adalah aktivitas guru, aktivitas siswa serta kemampuan guru dalam melaksanakan proses pembelajaran dengan menerapkan pendekatan kontekstual.

d. Refleksi

Pada tahap ini, guru/peneliti bersama observer dan teman sejawat menilai dan mendiskusikan kekurangan-kekurangan yang terdapat pada siklus I, untuk diperbaiki pada pelaksanaan siklus II.

\section{Pelaksanaan Siklus II}

a. Perencanaan

Peneliti menyiapkan perangkat pembelajaran yang merupakan perbaikan dan penyempurnaan apa yang telah dilaksanakan pada siklus sebelumnya mencakup: 1) merancang RPP 02; 2) lembar observasi (LO-2); 3) media, alat /bahan yang mendukung (MAB-2), dan 4) test formatif (TF-2)

b. Pelaksanaan Tindakan

Pada tahap pelaksanaan tindakan siklus II, tidak jauh beda dengan kegiatan pelaksanaan pada siklus I, yakni peneliti masih melaksanakan pembelajaran berdasarkan perangkat pembelajaran yang telah disediakanmeliputi; RPP-2, yang kemudian di akhir kegiatan, diadakan test.

c. Pengamatan/Observasi

Tahap pengamatan/observasi tindakan pun tetap dijalankan bersamaan dengan kegiatan yanhg dilakukan oleh teman sejawat (kolaborator) dengan menggunakan lembar observasi (LO-2).

d. Refleksi

Pada tahap ini juga peneliti tetap kembali mengadakan diskusi dengan teman sejawat (kolaborator) begitu pun hal-hal yang didiskusikan masih mengacu pada: (a). analisis tindakan yang telah dilakukan, (b). membahas kesesuaian rencana dan tindakan yang telah dilaksanakan, dan (c). memaknai data yang telah diperoleh untuk kemudian membuat resume atau kesimpulan akhir.

\section{Data dan Teknik Pengumpulan Data}

Sumber data dalam penelitian ini adalah siswa dan guru. Jenis data adalah data kuantitatif dan data kualitatif.Data kuantitatif digunakan untuk menentukan nilai hasil belajar siswa pada setiap siklus tindakan pembelajaran yang dilakukan oleh guru dalam menerapkan pendekatan kontekstual dengan menggunakan tes evaluasi, sedangkan data kualitatif digunakan untuk 
menghimpun data tentang proses pelaksanaan pembelajaran dengan menggunakan lembar observasi sebagai instrumen.

Pengambilan data dilakukan dengan cara berikut ini.

1. Data hasilbelajar siswa diambil dengan menggunakan tes

2. Data tentang kondisi pelaksanaan pembelajaran dengan menggunakan pendekatan kontekstual diambil berdasarkan lembar observasi terhadap gurudan siswa.

3. Data tentang perubahan yang terjadi di kelas diambil dari jurnal refleksi diri.

\section{Teknik Analisis Data}

Untuk mengetahui tingkat kemampuan menulis karanganatau ketuntasan belajar, menggunakan rumus sebagai berikut:

Rumus menghitung persentase hasil observasi $=\frac{S \quad P \quad n a}{S} \quad M \quad x 100$

Untuk menghitung persentase ketuntasan hasil belajar siswa secara klasikal menggunakan rumus sebagai berikut:

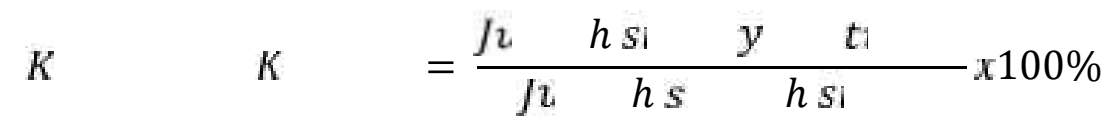

\section{Indikator Kinerja}

Indikator keberhasilan dalam penelitian ini terdiri atas :(a) indikator $\mathrm{t} \epsilon$ keterlaksanaan skenario pembelajaran, dan (b) indikator peninধ hasilbelajarsiswa, skenario pembelajaran dikatakan terlaksana dengan baik apabila minimal $80 \%$ skenario pembelajaran terlaksana, hasil belajar mengarang siswa dikatakan tuntas apabila minimal $80 \%$ siswa telah memperoleh nilai $\geq 70$.

\section{HASIL PENELITIAN DAN PEMBAHASAN}

\section{Kemampuan Menulis Karangan}

Hasil penelitian menunjukkan bahwa penerapan pendekatan kontekstual memiliki dampak positif dalam meningkatkan hasilpembelajaran menulis karangan pada siswa kelas VI SD Negeri 87 Kendari. Hal ini dapat dilihat dari adanya peningkatan hasil belajar siswa pada setiap siklus. Pada tes siklus I, nilai rata-rata hasil belajar mencapai 74,2 dengan persentase ketuntasan $72,72 \%$, pada tes siklus II nilai rata-rata meningkat menjadi 79,5 dengan persentase ketuntasan $90,90 \%$. Untuk lebih jelasnya mengenai peningkatan hasil belajar siswa disajikan pada gambar 1 berikut: 


\section{Gambar 1: Grafik Peningkatan Rata-rata Hasil Belajar Siswa}

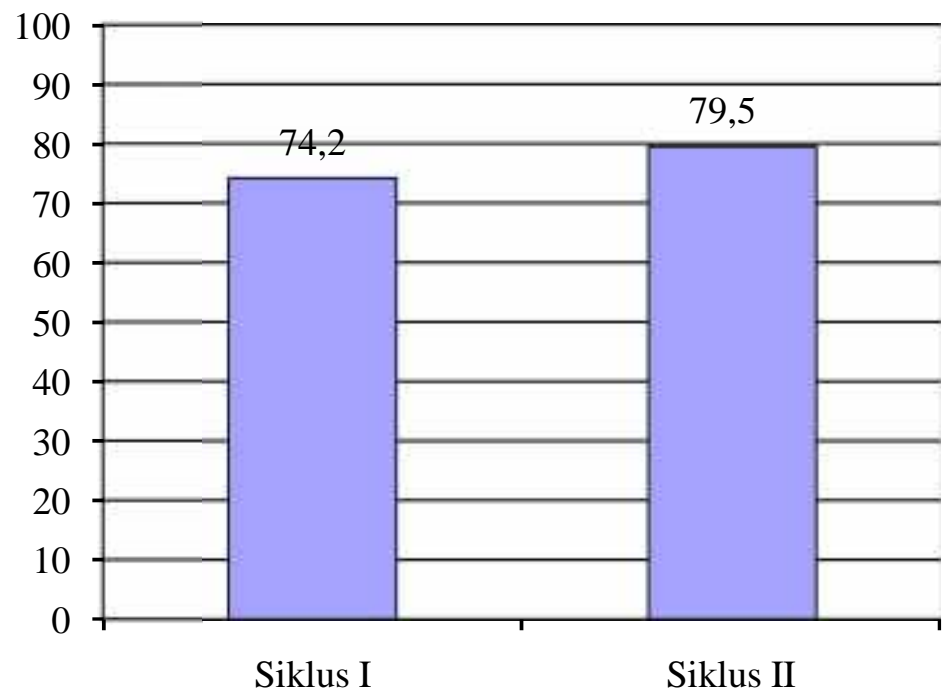

Berdasarkan grafik 4.1 di atas nampak bahwa rata-rata hasil belajar siswa mengalami peningkatan dari siklus I ke siklus II yakni pada siklus I, rata-rata hasil belajar siswa sebesar 74,2 meningkat menjadi 79,5 pada siklus II dengan peningkatan sebesar 1,82 .

Grafik peningkatan ketuntasan belajar siswa disajikan pada gambar 2 berikut.

Gambar 2 Grafik Peningkatan Ketuntasan Belajar Siswa

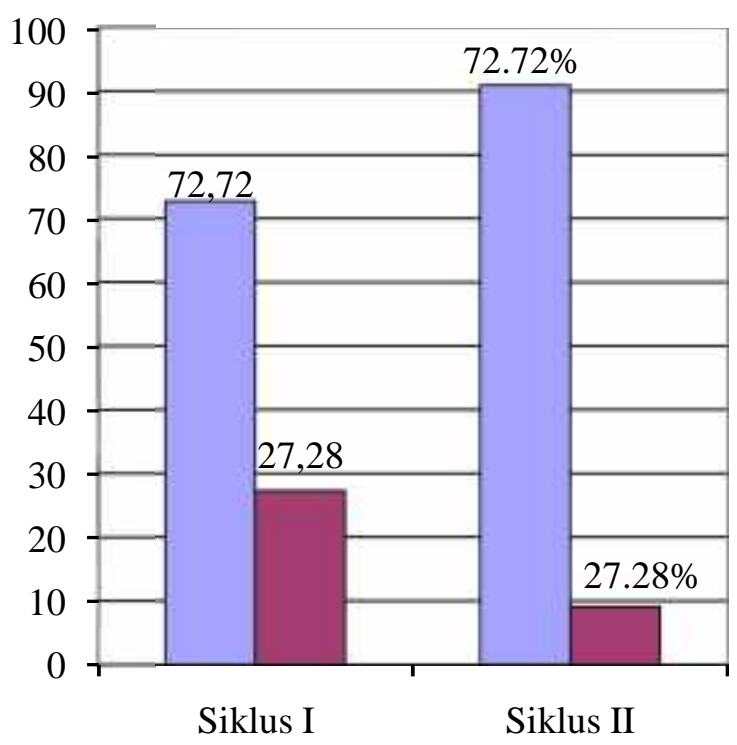

口Tuntas

$\square$ Tidak Tuntas

Berdasarkan grafik 2 di atas nampak bahwa ketuntasan belajar siswa mengalami peningkatan dari siklus I ke siklus II yakni pada siklus I, persentase ketuntasan hasil belajar siswa siklus I sebesar 72,72\%, yang tidak tuntas sebesar 27,28\% mengalami peningkatan pada siklus II, yakni persentase ketuntasan klasikal pada siklus II sebesar 90,90\% sedangkan persentase yang tidak tuntas sebesar 9,10\%. 


\section{Kegiatan Siswa dalam Pembelajaran}

Analisis hasil observasi kegiatan siswa dalam pembelajaran menunjukkan bahwa penerapan pendekatan kontekstual di kelas VI SD Negeri 87 Kendari memiliki dampak positif dalam meningkatkan aktivitas siswa. Hal ini dapat dilihat dari peningkatan hasil observasi kegiatan siswa pada setiap siklus. Persentase kegiatan siswa dalam mengikuti proses pembelajaran pada siklus I sebesar $70 \%$ meningkat menjadi $90 \%$ pada siklus II dengan peningkatan sebesar $20 \%$. Untuk lebih jelasnya mengenai peningkatan aktivitas siswa dalam pembelajaran disajikan pada gambar 4.3 berikut.

\section{Gambar 3: Grafik Peningkatan Aktivitas Siswa}

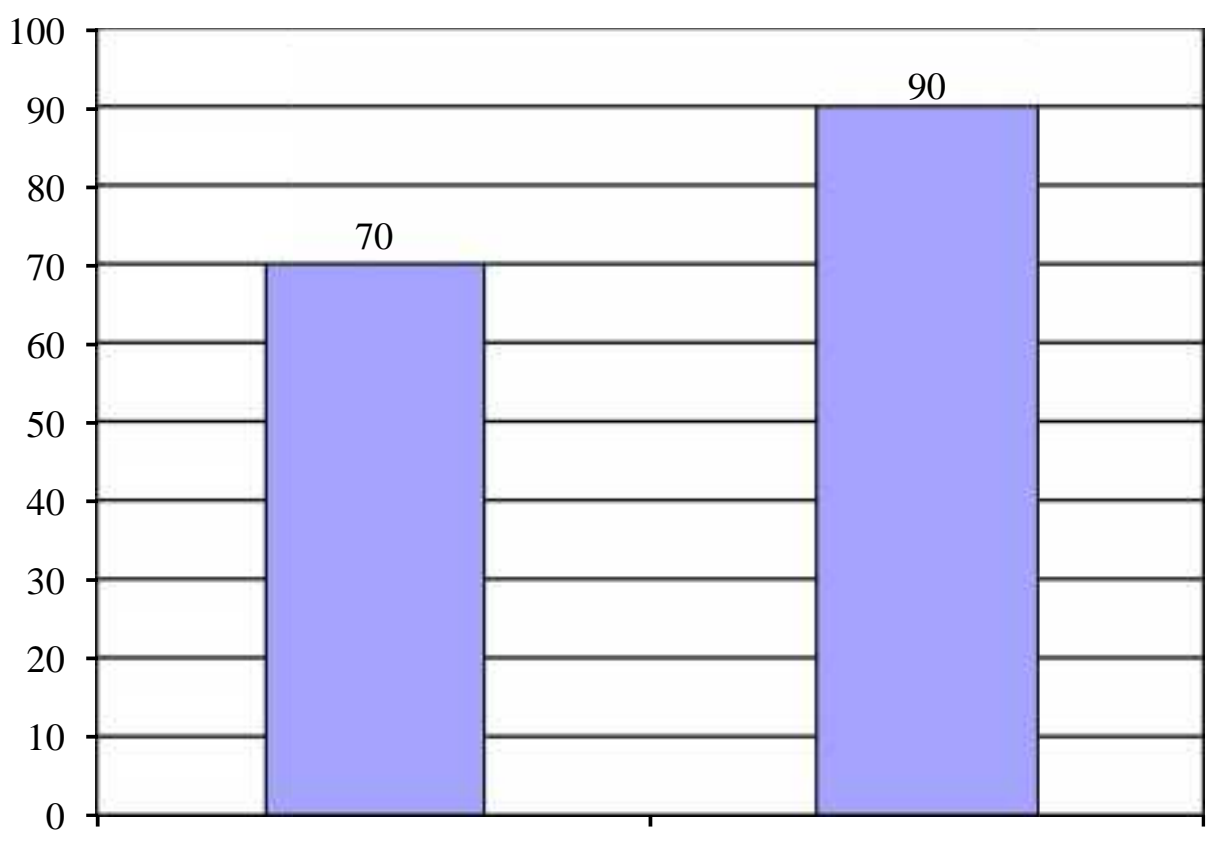

Siklus I

Siklus II

Berdasarkan grafik 3 di atas nampak bahwa persentase aktivitas siswa dalam pembelajaran mengalami peningkatan dari siklus I ke siklus II yakni pada siklus I sebesar $70 \%$ meningkat menjadi $90 \%$ pada siklus II dengan peningkatan sebesar $20 \%$.

\section{Kegiatan Guru dalam Pembelajaran}

Analisis hasil observasi kegiatan guru dalam pembelajaran menunjukkan bahwa penerapan pendekatan kontekstual di kelas VI SD Negeri 87 Kendari memiliki dampak positif dalam meningkatkan aktivitas guru. Hal ini dapat dilihat dari peningkatan hasil observasi kegiatan guru pada setiap siklus. Persentase kegiatan guru dalam melaksanakan pembelajaran pada siklus I sebesar $70 \%$ meningkat menjadi $90 \%$ pada siklus II dengan peningkatan 20\%.Untuk lebih jelasnya disajikan pada gambar 4 berikut. 


\section{Gambar 4: Grafik Peningkatan Aktivitas Guru}

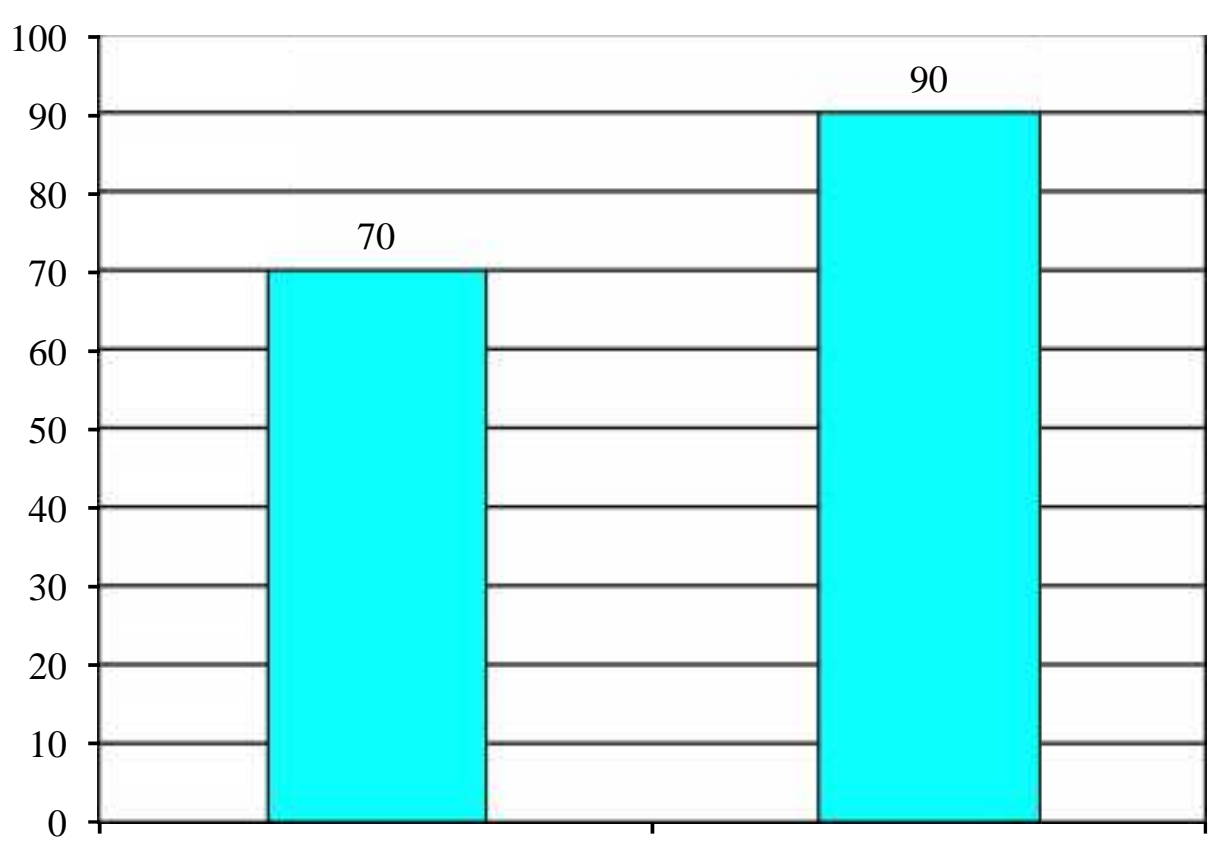

Siklus I

Siklus II

Berdasarkan grafik 4 di atas nampak bahwa persentase aktivitas guru dalam pembelajaran mengalami peningkatan dari siklus I ke siklus II yakni pada siklus I sebesar $70 \%$ meningkat menjadi $90 \%$ pada siklus II dengan peningkatan sebesar $20 \%$.

\section{PENUTUP}

\section{Kesimpulan}

Berdasarkan analisis data dan pembahasan hasil penelitian, maka dapat disimpulkan sebagai berikut.

1. Penerapan pendekatan kontekstual dalam mengajarkan bahasa Indonesia pada materi menulis karangan dapat meningkatkan hasil belajar siswa yakni rata-rata hasil belajar siswa pada siklus I sebesar 74,2 dengan persentase ketuntasan $72,72 \%$ meningkat pada siklus II yakni rata-rata hasil belajar siswa mencapai 79,5 dengan persentase ketuntasan 90,90\%.

2. Persentase kegiatan siswa dalam mengikuti pembelajaran meningkat dari siklus I sebesar $70 \%$ menjadi $90 \%$ pada siklus II.

3. Persentase kegiatan guru dalam melaksanakan pembelajaran pada siklus I sebesar $70 \%$ meningkat menjadi $90 \%$ pada siklus II.

\section{Saran}

Berdasarkan kesimpulan penelitian yang telah dikemukakan di atas dapat diajukan beberapa saran berikut.

1. Bagi guru kelas sekolah dasar, hendaknya menerapkan pendekatan kontekstualdalam pembelajaran menulis karangan karena memiliki dampak positif dalam meningkatkan hasil belajar siswa.

2. Agar pelaksanaan pembelajaran dengan pendekatan kontekstualdapat lebih efektif hendaknya dipadukan dengan strategi pembelajaran lainnya. 
3. Untuk melihat dampak yang lebih luas terhadap pembelajaran dengan penerapan pendekatan kontekstualperlu dilakukan penelitian serupa pada konsep-konsep lain yang karakterisitk materinya sama.

\section{DAFTAR PUSTAKA}

Akhmadi, Mukhsin, 1989, Strategi Belajar Mengajar Keterampilan Berbahasa dan Apresiaiasi sastra. Malang: Y.A3.

Aqib 2006. Karya Tulis Ilmiah Bagi Pengembangan Profesi Guru. Bandung: Yrama Widya.

Depdiknas, 2003. Kurikulum Berbasis Kompetensi. Jakarta: Depdikbud

Hamira, 2011. Meningkatkan Kemampuan Menulis Laporan Pengamatan pada Siswa Kelas V SD Negeri Lawonua dengan Menggunakan Pendekatan Kontekstual. Skripsi. Kendari Universitas Halu Oleo.

Hernowo, 2002. Mengingat Makna, Mengubah Paradigma Membaca dan menulis secara Radikal. Bandung: Kaifa.

Hernowo. 2004. Quantum Writing. Bandung: Kaifa.

Mukhlis, Abdul. (Ed). 2000. Penelitian Tindakan Kelas. Makalah Panitia Pelatihan Penulisan Karya Ilmiah untuk Guru-Guru se-Kabupaten Tuban.

Nurhadi, 2003. Pembelajaran Kontekstual dan Penerapannya dalam KBK. Malang: Universitas Malang.

Permana, Maryani. T, 2009. "Meningkatkan Kemampuan Siswa dalam Menulis Karangan Melalui Penggunaan model pembelajaran kontekstual di Kelas V SDN Cibulan II Desa Cibulan Kecamatan Lemahsugih Kabupaten Majalengka". Skripsi. Universitas Pendidikan Indonesia. Sumedang.

Rofiudin, 1997. Pendidikan Bahasa dan Sastra Indonesia Di Kelas Tinggi. Jakarta: Bumi Aksara.

Rustana, C.E. 2002. Pembelajaran dan Pengajaran Kontekstual. Jakarta: Direktorat Pendidikan Dasar dan Menengah.

Semiawan. 1999. Perkembangan dan Belajar Peserta Didik. Jakarta: Departemen Pendidikan Nasional, Direktorat Jenderal Pendidikan Tinggi, Proyek Pendidikan Guru Sekolah Dasar.

Sinolungan, R.E. 1997. Psikologi Perkembangan Peserta Didik. Jakarta: Gunung Agung.

Slameto, 2003. Belajar dan Faktor-Faktor yang Mempengaruhinya. Jakarta: Rineka Cipta.

Slameto. 1991. Proses Belajar Mengajar Dalam Sistem Kredit Semester (SKS). Jakarta: Bumi Aksara.

Soetomo. 1993. Dasar-dasar Interaksi Belajar Mengajar. Surabaya: Usaha Nasional.

Suparno, Paul. 1997. Filsafat Konstruktivisme Dalam Pendidikan, Yogyakarta, Kanisius.

Nur Muhamad. 2000, Pengajaran Berpusat Kepada Siswa dan Pendekatan Kontruktivis Dalam Pengajaran, Surabaya: Unesa University Press.

Tarigan, 1996. Bentuk dan Pilihan Kata dalam Menulis. Jakarta: Pusat penelitian dan Pengembangan Bahasa 